\title{
Nosocomial infections in ICU comparing HIV infected and not infected patients
}

\author{
AM Costa E Silva*, ES Abreu, RDF Feijó, DWCL Santos, F Siroma, CMM Pinto, NJF Cavalcante, R Richtmann \\ From International Conference on Prevention \& Infection Control (ICPIC 2011) \\ Geneva, Switzerland. 29 June - 2 July 2011
}

\section{Introduction / objectives}

This study describe the epidemiology of nosocomial (NI) notified at ICU in a tertiary level teaching hospital specialized in infectious diseases comparing adults patients HIV infected and not infected

\section{Methods}

From January to December/2009 all patients admitted for more than 48hours at our 17 beds ICU were included. NI definitions were based on the CDC criteria.

\section{Results}

119 NI were notified among 486 patients; the most frequent NI was pneumonia $(n=53 ; 44,5 \%)$, followed by primary bloodstream infection (BSI) in 27(22.7\%), cardiovascular system - arterial or venous infection (CVS-VASC) $(\mathrm{n}=16 ; 13.4 \%)$, urinary tract infection $(\mathrm{n}=12 ; 10.1 \%)$, intra-abdominal infections $(\mathrm{n}=6 ; 5 \%)$, soft tissue/skin infections $(n=4 ; 3,5 \%)$, and surgical site infection $(n=1 ; 0.8 \%)$. Among pneumonias, ventilator-associated pneumonia were seen in 42 cases $(79,2 \%)$. Comparing HIV infected and not infected patients, the incidence of VAP in HIV+ was $38.6 \% \mathrm{X}$ $30.6 \% \mathrm{HIV}$-; primary BSI in HIV+ was $22.8 \% \mathrm{X} 22.4 \%$ in HIV-; CVS-VASC in HIV+ was $10 \% \mathrm{X} 18.3 \%$ in HIV-; urinary tract infection in HIV+ was $12.8 \% \mathrm{X}$ $6.1 \%$ in HIV-; lower respiratory tract infection (nonVAP) in HIV+ was 5,7\% X 14,3\% in HIV-; intraabdominal infections in HIV+ was 7,1\% X $2 \%$ in HIV-; soft tissue/ skin infections in HIV+ was $1,4 \% \times$ X $6,1 \%$ in HIV-; and surgical site infections in HIV+ was1,4\% X zero in HIV-. There was no significant difference comparing groups.

Hospitalar Infection Control Comission, Instituto de Infectologia Emilio Ribas, São Paulo, Brazil

\section{Conclusion}

There were no statistical difference in the topography of NI in HIV infected or not infected at ICU.

\section{Disclosure of interest}

None declared.

Published: 29 June 2011

doi:10.1186/1753-6561-5-S6-P78

Cite this article as: Costa E Silva et al:: Nosocomial infections in ICU

comparing HIV infected and not infected patients. BMC Proceedings 2011 5(Suppl 6):P78.
Submit your next manuscript to BioMed Central and take full advantage of:

- Convenient online submission

- Thorough peer review

- No space constraints or color figure charges

- Immediate publication on acceptance

- Inclusion in PubMed, CAS, Scopus and Google Scholar

- Research which is freely available for redistribution

Submit your manuscript at www.biomedcentral.com/submit
C Biomed Central

\section{Biomed Central}

